\title{
Radon Monitoring in Soil Gas and Ground Water for Earthquake Prediction Studies in North West Himalayas, India
}

\author{
Surinder Singh ${ }^{1, *}$, Arvind Kumar ${ }^{1}$, Bikramjit Singh Bajwa ${ }^{1}$, Sandeep Mahajan ${ }^{1}$, \\ Vinod Kumar ${ }^{1}$, and Sunil Dhar ${ }^{2}$ \\ ${ }^{1}$ Department of Physics, Guru Nanak Dev University, Amritsar-143005, India \\ ${ }^{2}$ Department of Geology, Government College, Dharamsala, Himachal Pradesh, India
}

Received 25 November 2008, accepted 17 July 2009

\begin{abstract}
Continuous monitoring of soil gas radon at Sarol and the daily monitoring of radon concentration in water at Banikhet is carried out in Chamba valley of North West Himalayas, India "a well known seismic zone" to study the correlation of radon anomalies in relation to seismic activities of the region. Radon monitoring in soil gas was carried out by using Barasol probe manufactured by Algade France and the radon content in water was recorded using RAD7 radon monitoring system of Durridge Company, USA. The effect of meteorological parameters viz. temperature and pressure on soil gas radon emission has been studied. Correlation coefficient has been calculated between radon in soil gas, soil temperature and soil pressure. The radon anomalies observed in the region have been correlated with the seismic events in the magnitude range 2.2 to 5.0 recorded by Wadia Institute of Himalayan Geology Dehradun in NW Himalayan. Empirical equations between earthquake magnitude, epicentral distance and precursor time were examined, and respective constants were determined.
\end{abstract}

Key words: Radon, NW Himalayas, Barasol probe, RAD7, Earthquake precursor

Citation: Singh, S., A. Kumar, B. S. Bajwa, S. Mahajan, V. Kumar, and S. Dhar, 2010: Radon monitoring in soil gas and ground water for earthquake prediction studies in North West Himalayas, India. Terr. Atmos. Ocean. Sci., 21, 685-695, doi: 10.3319/TAO.2009.07.17.01(TT)

\section{INTRODUCTION}

The prediction of earthquakes remains one of the most frustrating issues in the Earth Sciences and many independent forms of evidence have been cited to predict the occurrence of major seismic events. Earthquake prediction research has greatly increased our understanding of earthquake source mechanism, the structural complexities of fault zones, and earthquake recurrence interval, expected at a given location. Radon is established as a useful geochemical precursor. Anomalous behavior of radon in soil and groundwater can be used as a reliable precursor for an impending earthquake. The first evidence of a correlation between radon and earthquake occurrence came from observation of radon concentration in well water prior to the Tashkent earthquake of 1966 (Ulomov and Mavashev 1967). This evidence stimulated research work in this area soon afterwards in many countries. Radon observa-

\footnotetext{
* Corresponding author

E-mail: surinder_s1951@yahoo.co.in
}

tions, both in soil-gas and in groundwater, revealed many precursory changes in its concentration before an earthquake (Mogro-Campero et al. 1980; Talwani et al. 1980; Fleischer 1981; Liu et al. 1984/85; Virk and Singh 1992; Igarashi et al. 1995; Chyi et al. 2005; Walia et al. 2005, 2006; Yang et al. 2005; Einarsson et al. 2008; Kumar et al. 2009).

Investigations throughout the world over the past 15 years provide evidence, which indicate that significant variations of radon concentration may occur in association with major geophysical events such as earthquakes and volcanic eruptions (Al-Tamimi and Abumurad 2001; Chyi et al. 2005; Fu et al. 2005; Walia et al. 2005, 2006; Yang et al. 2005; Singh et al. 2006; Kumar et al. 2009). Due to such observed correlation, radon is considered as one of the few promising precursors for earthquakes.

Radon is product of uranium decay series with a half life of 3.8 days. Radon displays poor intrinsic mobility due to its short half-life, and therefore in a diffusive system it obviously comes from a short distance below the measuring 
instrument. Deep origin signals can be observed only if convection/advection occurs, radon being carried upward to the subsurface by a rising gas/water column (e.g., Etiope and Lombardi 1995; Yang et al. 2003).

In the present Investigations the program of radon monitoring at Chamba Valley (Fig. 1) of NW Himalayas, India was initiated on December 2006. The continuous soil gas monitoring is carried out at Sarol (Chamba) using Barasol probe and radon monitoring in groundwater at Banikhet (Chamba) using RAD7 radon monitoring system respectively. The analytical protocol in the present work is based on the analysis of radon emitted from the fault planes, a novel geochemical precursor that may ultimately help predicting the earthquake activity.

\section{GEOLOGY OF THE AREA}

The Chamba valley lies between the Pir Panjal and the Dhauladhar range of lesser Himalaya. The radon monitoring stations fall in the immediate vicinity of outer Himalayan zones and the lesser Himalayan zones comprising the Siwalik hills with altitude varying up to $4500 \mathrm{~m}$ and valley with $900 \mathrm{~m}$, general altitude northwards. The radon monitoring stations, as shown in Fig. 1, were chosen to be along the MBT and MCT to have maximum radon release from the deep source. The rock units lying between the MBT and the
MCT are included under the lesser Himalayan zone. The rocks present in the Chamba area are granite agglomeratic slate and shale.

\section{EXPERIMENT TECHNIQUE}

\subsection{Radon Monitoring in Soil}

For continuous monitoring of radon, temperature and pressure in soil gas, BMC2 radon probe manufactured by Algade France is used. It consists of radon Sensor (Silicon alpha sensitive detector) that records the radon gas enters in to the detection chamber. The $\mathrm{BMC} 2$ probe is composed of a detection unit, electronics and a battery unit fitted inside a mechanism consisting of a tube made of an epoxy glass material $61 \mathrm{~mm}$ in diameter and $500 \mathrm{~mm}$ long. As standard, an 8 pin connector provides the probe interconnection and control. The connector has an air and water tight index of IP 68 when covered by the cap. The battery unit holds $2 \times$ $1.5 \mathrm{~V}$ alkaline batteries. Two good quality alkaline batteries give the probe more than 6 months' independent operation. The memory capacity is one year. It is installed in soil at a depth of $1.10 \mathrm{~m}$ below the ground at Sarol in Chamba valley NW Himalaya India (Fig. 2). It detects alpha-particle emissions of radon in soil gas hourly. The detector sensitivity is 0.02 pulses $\mathrm{h}^{-1}$ for $1 \mathrm{~Bq} \mathrm{~m}^{-3}$ and the saturation volumetric activity is $3 \mathrm{MBq} \mathrm{m}^{-3}$.

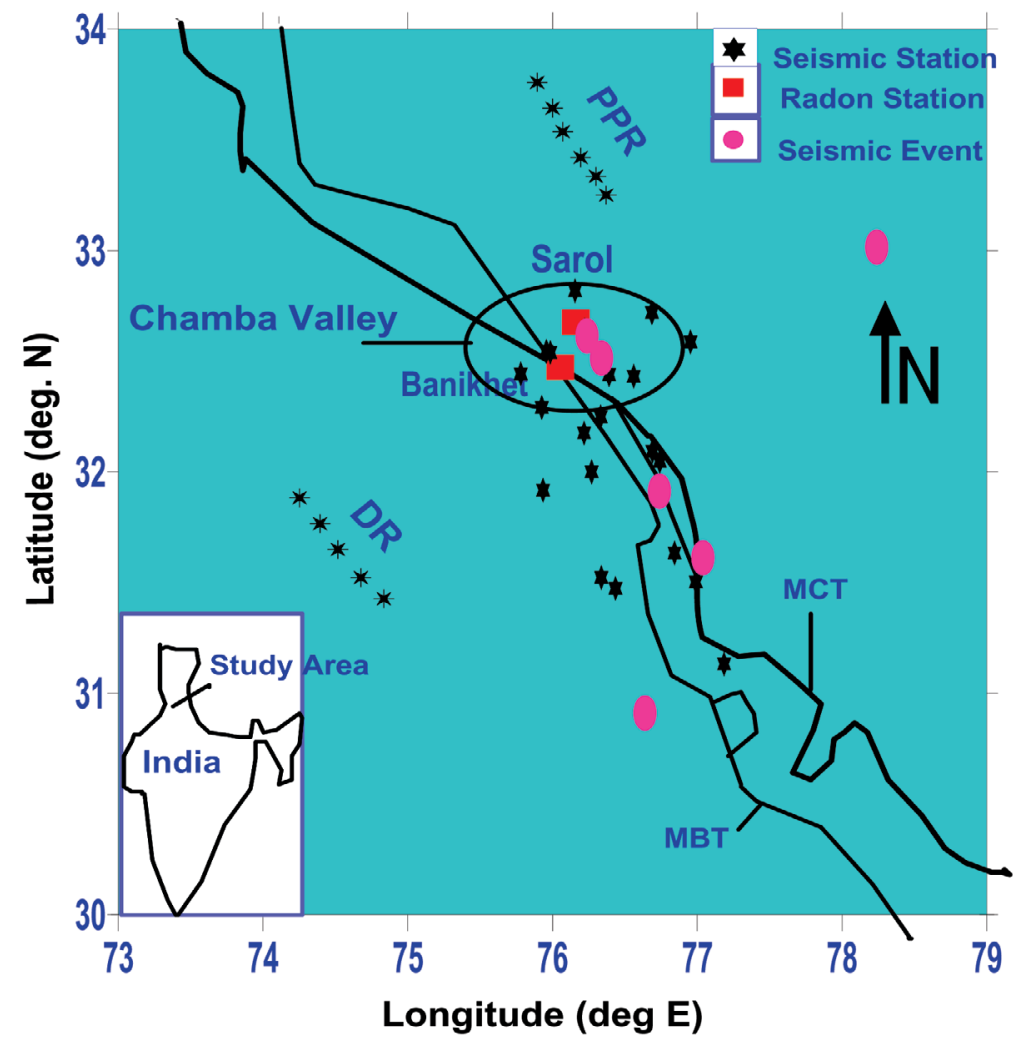

Fig. 1. Locations of radon monitoring stations, seismic stations and epicenters on a map of Northwest Himalaya. Labels used are as follows: MCT, main central thrust; MBT, main boundary thrust; and PPR, Pir Panjal Range; and DR, Dhauladhar range. 


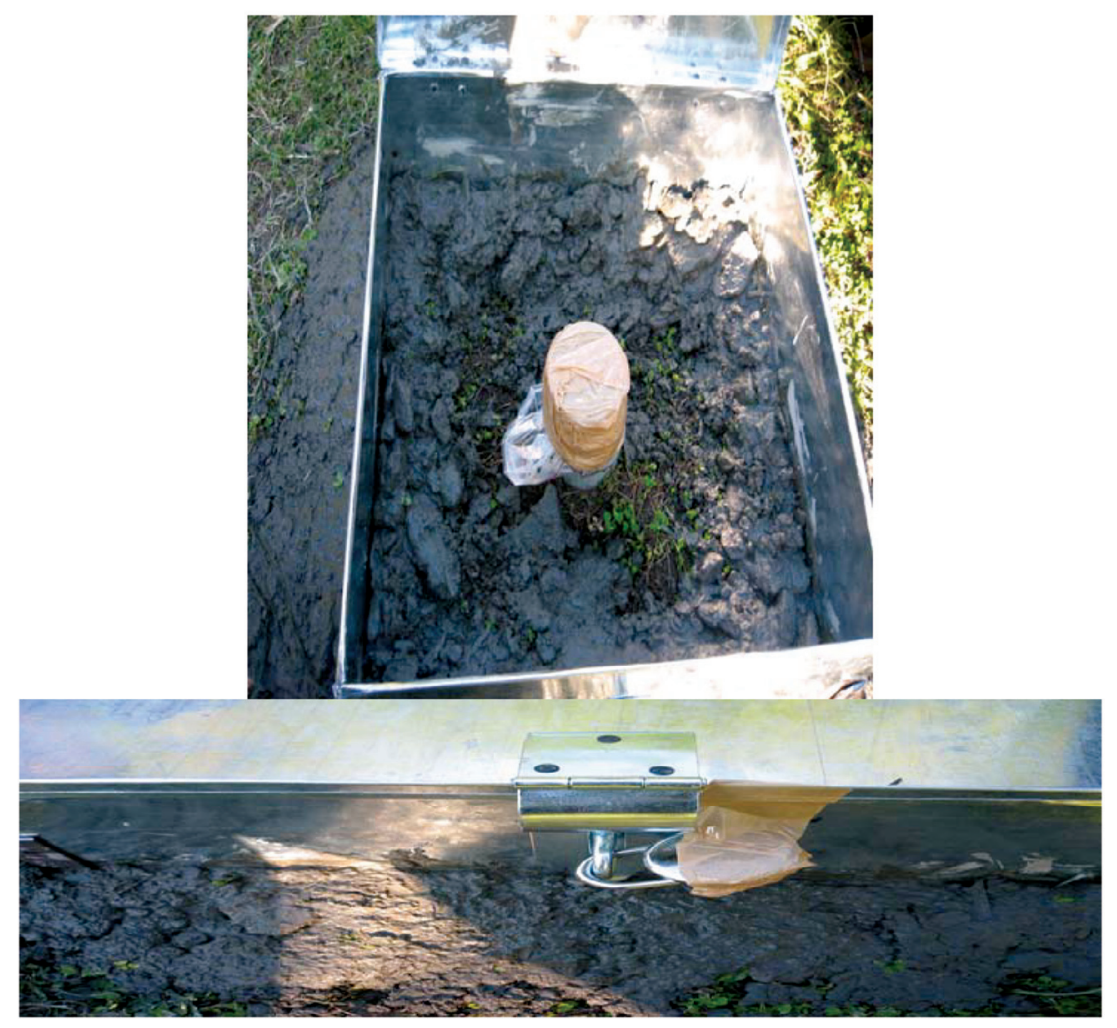

Fig. 2. View of an installed BMC2 Radon Probe in the field.

\subsection{Radon Monitoring in Water}

\subsubsection{Collection of Samples}

For the measurement of radon concentration a sample of $250 \mathrm{ml}$ water is collected daily from natural ground water source in Banikhet. The radon sampling is complicated by the fact that the gas easily escapes from water and therefore has to be done without any aeration which might lead to out gassing. So the water sample was collected slowly from the source so that there was no bubbling.

\subsubsection{RAD- $\mathrm{H}_{2} \mathrm{O}$ Technique}

RAD7 (Fig. 3) procured from Durridge Company USA has been used for monitoring Radon concentration in water. The method employs a closed loop aeration scheme whereby the air volume and water volume are constant and independent of the flow rate. The air recirculates through the water and continuously extracts the radon until a state of equilibrium develops. The $\mathrm{RAD}-\mathrm{H}_{2} \mathrm{O}$ system reaches this state of equilibrium within about 5 minutes, after which no more radon can be extracted from the water. The setup consists of three components, the RAD7, on the right, the vial, center front, and the tube of desiccant, top left. The case provides a convenient stand for the tube of desiccant, held up between the two clasps on the lid, and also for the vial in the foam cavity. During the five minutes of aeration before the state of equilibrium, more than $95 \%$ of the available radon is removed from the water.

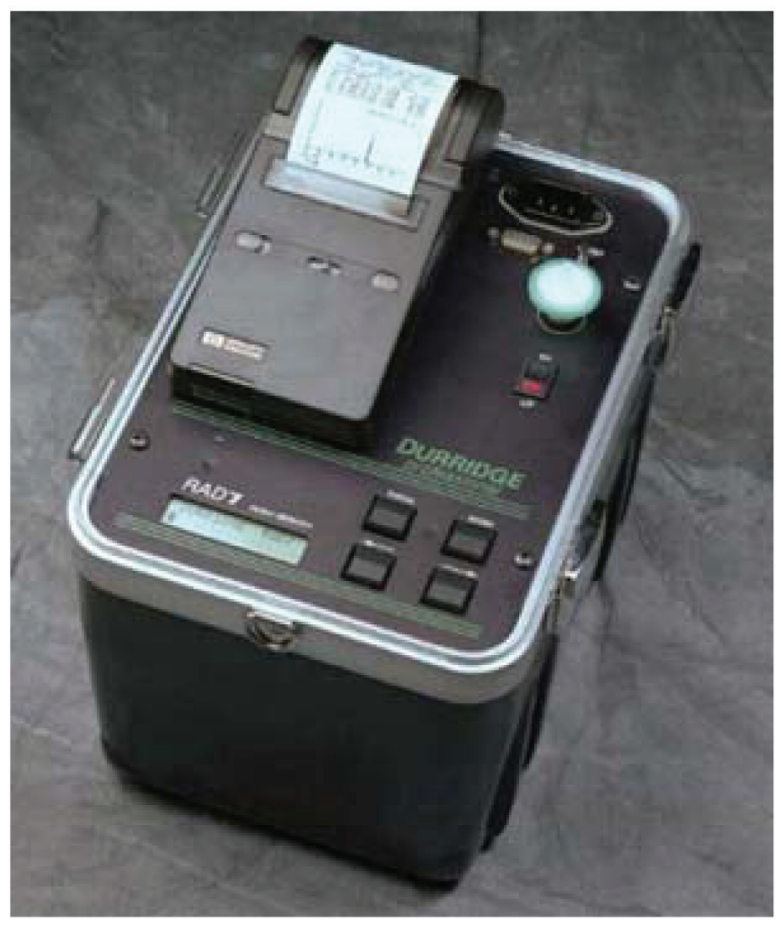

Fig. 3. Sketch of a RAD7 radon gas recorder. 


\section{RESULTS AND DISCUSSION}

The variation of radon concentration in soil gas along with the soil temperature and pressure at Sarol from December 2006 to September 2007 is shown in Fig. 4. The average value of radon for soil-gas at Sarol is reported to be $6 \mathrm{kBq} \mathrm{m}^{-3}$ with a standard deviation (Std.) of $5 \mathrm{kBq} \mathrm{m}^{-3}$. The percentage variation coefficient (Std./Avg.) of radon is $83 \%$ (Table 1). With few exceptions radon in general shows positive correlation with temperature i.e., the value of radon concentration increases as temperature increases and decreases with decrease in temperature. The correlation coefficient between radon and temperature is found to be 0.6 (Table 1). The average value of temperature for the given time window was $19^{\circ} \mathrm{C}$ with a standard deviation of $6^{\circ} \mathrm{C}$ and percentage variation coefficient of $29 \%$ (Table 1 ). The increase in radon concentration with temperature may be due to the increase in the diffusion rate with temperature (Singh et al. 1988; Sharma et al. 2000). Negative correlation coefficient -0.4 between radon and pressure has been found i.e., radon decreases with increase in pressure and increases with decreases in pressure. The average value of pressure for the given time window was 920 mbar with a standard deviation of 13 mbar and percentage variation coefficient of $1 \%$ (Table 1). This may be due to the fact that the increase of pressure may slow down the diffusion process there by decreasing the radon concentration in soil. The reason for low correlation coefficient between radon, temperature and pressure is that radon is also affected by other meteorological as well as geophysical/geochemical parameters. Our results for the effects of meteorological parameters viz. temperature and pressure on radon release corroborate the findings of the other authors (Singh et al. 1988; King and Minissale 1994; Singh and Virk 1994; Sharma et al. 2000; Mukherji et al. 2001).

\subsection{Correlation of Radon Anomalies in Soil and Water with Seismic Events}

In the present work seismic data was obtained from Wadia Institute of Himalayan Geology (WIHG), Dehradoon. As a part of the National Seismic Network, IMD has

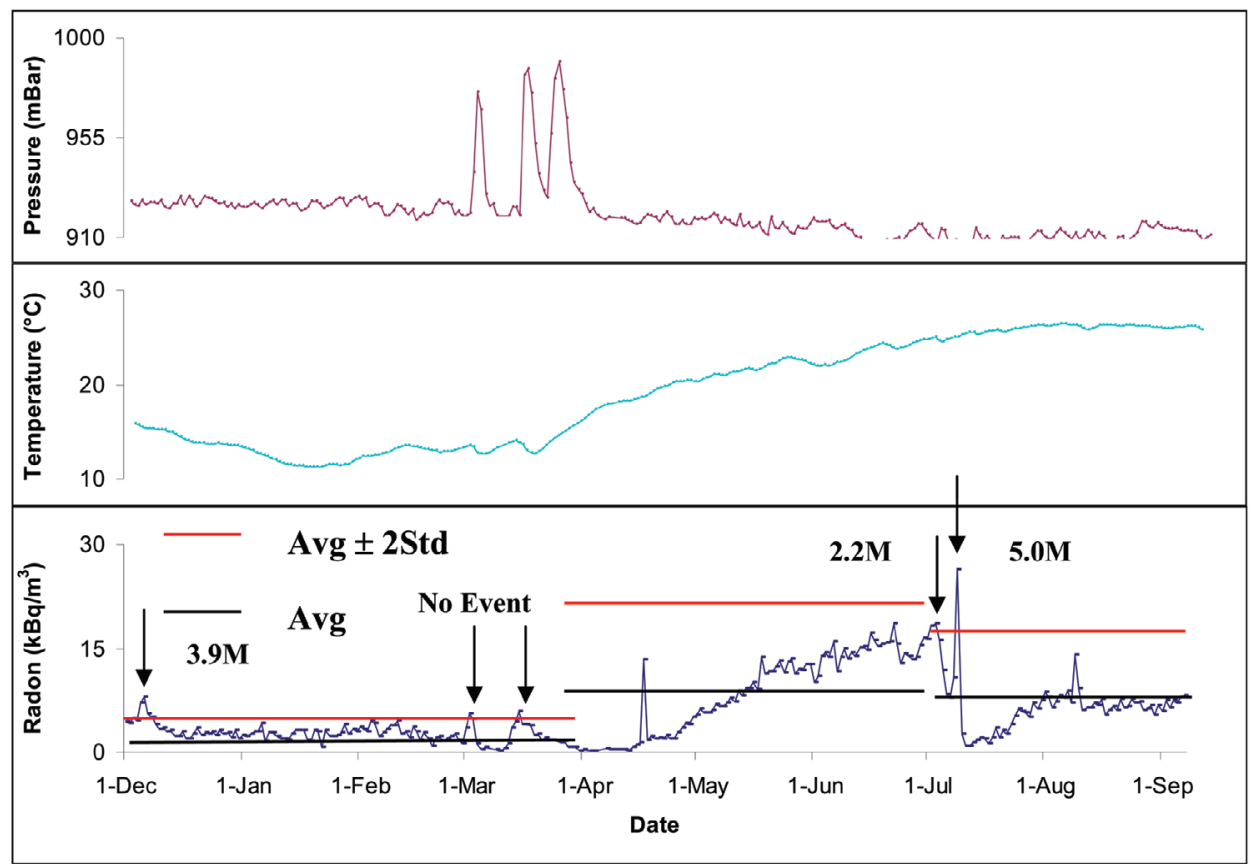

Fig. 4. Daily variation of radon concentration in soil gas along with soil temperature and pressure at Sarol from December 2006 to September 2007.

Table 1. Correlation Coefficient of radon concentration in soil-gas with soil temperature and pressure at Sarol.

\begin{tabular}{lcccc}
\hline Parameters & Average (Avg.) & $\begin{array}{c}\text { Standard Deviation } \\
\text { (Std.) }\end{array}$ & $\begin{array}{c}\text { \% Variation Coefficient } \\
\text { (Std./Avg.) }\end{array}$ & Correlation Coefficient \\
\hline Radon $\left(\mathrm{kBq} \mathrm{m}^{-3}\right)$ & 6 & 5 & 83 & - \\
Temperature $\left({ }^{\circ} \mathrm{C}\right)$ & 19 & 6 & 29 & 0.6 \\
Pressure (mbar) & 920 & 13 & 1 & -0.4 \\
\hline
\end{tabular}


been operating eight seismic stations in northwest Himalaya since 1963. WIHG upgraded the network in 1984 by adding seismic stations in Himachal and Garhwal Himalaya to monitor the seismic activity on a regional scale. The layout of 21 seismic stations in the Kangra-Chamba sector of Himachal Himalaya is shown in Fig. 1. The minimum spacing between pairs of stations is just 3 - $7 \mathrm{~km}$ (Banikhet-Dalhausei; Deol-Beed) with average spacing in the central part of the network ranging from 20 to $30 \mathrm{~km}$. The 20 digital seismic stations are equipped with portable high-quality three component CMG-3T (120 sec natural period), CMG-40T (30 sec natural period) broadband, and CMG-40T1 short period GURLAP seismometers (1 sec natural period). GPS synchronized data are digitized at 100 samples sec $^{-1}$ with a dynamic range of more than $138 \mathrm{db}$ (24 bits resolution). 2.5 magnitudes is the threshold detection in Himachal Pradesh and this threshold is same in the whole Himachal Himalaya.

The soil gas radon data shows anomalous behaviour with different meteorological and geophysical parameters. The average value of radon for soil gas at Sarol from December to March is reported to be $3 \mathrm{kBq} \mathrm{m}^{-3}$ with a standard deviation (Std.) of $1 \mathrm{kBq} \mathrm{m}^{-3}$. The percentage variation coefficient (Std./Avg.) of radon is $49 \%$. The average value of radon for soil-gas at Sarol from April to June is reported to be $9 \mathrm{kBq} \mathrm{m}^{-3}$ with a standard deviation (Std.) of $6 \mathrm{kBq} \mathrm{m}^{-3}$. The percentage variation coefficient (Std./Avg.) of radon is $63 \%$. The average value of radon for soil-gas at Sarol from July to September is reported to be $7 \mathrm{kBq} \mathrm{m}^{-3}$ with a standard deviation (Std.) of $4 \mathrm{kBq} \mathrm{m}^{-3}$. The percentage variation coefficient (Std./Avg.) of radon is $61 \%$. The high average radon concentration from April to June is due to high temperature as well as well as high wind velocity during this time period. Seasonal average of radon in soil gas with soil temperature and pressure at Sarol are calculated and used to find the radon anomaly to minimize the effect of meteorological parameters on radon emission for the given time window (Table 2). In order to identify possible threshold values of the anomalous radon concentration various statistical methods have been used by different authors in the past (Lepeltier 1969; Klusman 1993; Guerra and Lombardi 2001; Fu et al. 2005; Walia et al. 2005; Yang et al. 2005; Kumar et al. 2009). The very common practice of considering the mean plus " $n$ " standard deviation is generally accepted as an anomaly in soil gas and is found to be convenient for soil gas survey interpretations (Guerra and Lombardi 2001; Fu et al. 2005; Singh et al. 2006; Walia et al. 2008). In our context of radon concentration the statistical threshold value of anomalies is fixed at the average plus two standard deviation $(2 \sigma)$ for positive anomaly and average minus two standard deviation $(2 \sigma)$ for negative anomalies in soil gas and ground water. The radon value near zero data is not taken in to consideration because due to some sampling or other technical problems or with near zero data may have been experienced gas-leak problem.

Radon anomalies recorded in soil gas at Sarol from December 2006 to September 2007 are shown in Table 3. Five soil gas radon anomalies were recorded. The first radon anomaly was recorded on 06 December 2006 which was followed by the event of magnitude 3.9 which occurred on 06 December 2006 respectively in NW Himalayas. The second and third radon anomaly was recorded on 02 March 2007 and 15 March 2007 respectively and not followed by an event in NW Himalayas. The fourth anomaly was recorded on 03 July 2007 followed by the event $2.2 \mathrm{M}$ $\left(31.9^{\circ} \mathrm{N}, 76.7^{\circ} \mathrm{E}\right)$ four days prior to the event which occurred on 07 July 2007. The fifth radon anomaly was recorded on 09 July 2007 which was followed by 5.0 M events in NW

Table 2. Seasonal average values of radon concentration in soil-gas with soil temperature and pressure at Sarol.

\begin{tabular}{|c|c|c|c|c|}
\hline Parameters & Time Period & Average (Avg.) & $\begin{array}{c}\text { Standard Deviation } \\
\text { (Std.) }\end{array}$ & $\begin{array}{c}\% \text { Variation Coefficient } \\
\text { (Std./Avg.) }\end{array}$ \\
\hline \multirow{3}{*}{ Radon $\left(\mathrm{kBq} \mathrm{m}^{-3}\right)$} & December 2006 - March 2007 & 3 & 1 & 49 \\
\hline & April - June 2007 & 9 & 6 & 63 \\
\hline & July - September 2007 & 7 & 4 & 61 \\
\hline \multirow{3}{*}{ Temperature $\left({ }^{\circ} \mathrm{C}\right)$} & December 2006 - March 2007 & 13 & 1 & 10 \\
\hline & April - June 2007 & 22 & 2 & 10 \\
\hline & July - September 2007 & 26 & 1 & 2 \\
\hline \multirow{3}{*}{ Pressure (mbar) } & December 2006 - March 2007 & 930 & 15 & 16 \\
\hline & April - June 2007 & 915 & 4 & 0.4 \\
\hline & July - September 2007 & 911 & 3 & 0.2 \\
\hline
\end{tabular}


Singh et al.

Table 3. Correlation of soil gas Radon anomalies recorded at Sarol with seismic event.

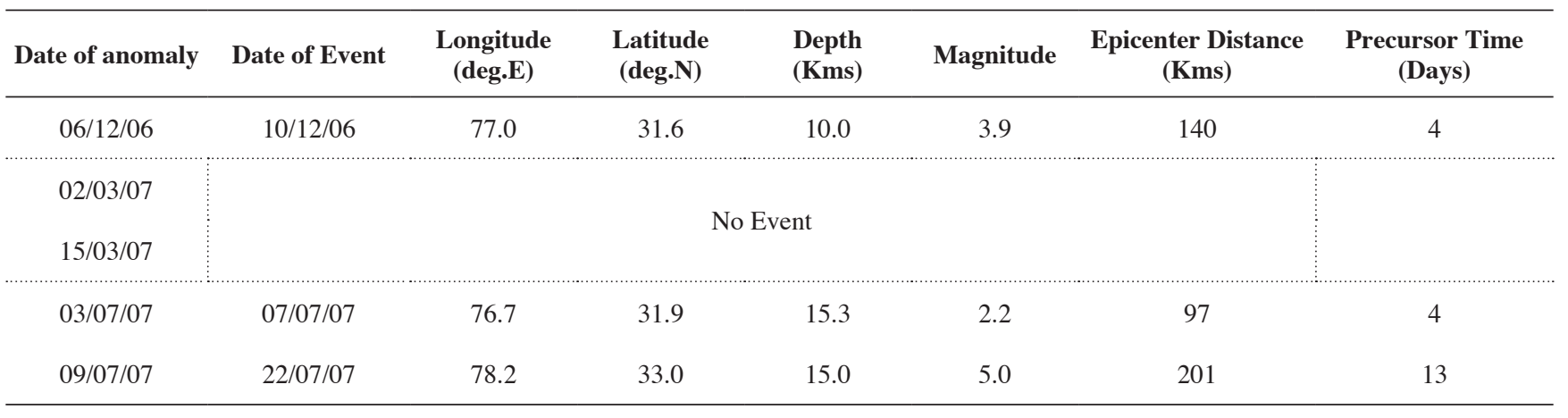

Himalayas about two week prior to the event that occurred on 22 July 2007.

The daily variation of radon concentration in water at Banikhet from 12 December 2006 to 21 December 2007 is shown in Fig. 5. The seasonal average of radon in ground water (Table 4) shows that ground water radon data do not show much anomalous behaviour with different meteorological and geophysical parameters as in the case of soil gas. Radon anomalies recorded in ground water at Banikhet in the above time window are shown in Table 5. Five positive and four negative radon anomalies were recorded. The first positive radon anomaly in ground water was recorded on 22 December 2006 followed by event of magnitude 3.2 which occurred on 25 December 2006 respectively in NW Himalayas. The second positive radon anomaly was recorded on 02 May 2007 followed by the event 4.0 M which occurred on the same day in NW Himalayas. The first negative radon anomaly in ground water was recorded on 19 May 2007 which was not followed by an event in NW Himalayas. The second negative radon anomaly in ground water was recorded on 08 July 2007 followed by the Uttarakashi earthquake of magnitude 5.0 after fifteen days of the anomaly. This event is also correlated with positive soil gas anomaly recorded on 08 July 2007. The difference in the nature of anomalies in case of soil and water may be due to the difference in the radon source. Moreover the radon water source (Banikhet) lies exactly on the fault system where as the radon soil source is slightly away from the fault. The third positive and negative anomaly were recorded on 21 August 2007 and 01 September 2007 respectively and not followed by any event in NW Himalayas. The fourth negative anomaly in water was recorded on 27 September 2007 followed by event of magnitude 3.7 in NW Himalayas that occurred on 04 October 2007. The fourth positive anomaly was recorded on 02 November 2007 respectively not followed by any event in NW Himalayas. Fifth positive radon anomaly was recorded on 03 December 2007 followed by the event 2.9 magnitude in the NW Himalayas.

An enhanced radon concentration in the deep seated natural water and to lesser extent in soil is assigned to de- velopment of microcracks, fissure and fracture due to the dilatancy prior to earthquake. According to dilatancy mechanism for earthquake occurrence (Scholz et al. 1973) when regional stress increases, dilation of rock masses could cause an increase in the surface area of rocks due to cracking, or in the flow rate of pore fluids as they are forced out of the interstitial space. Both of these processes will enhance the transport of radon from its original enclosures in to the ground water. The increase in soil-gas radon concentration before an earthquake may be due to the strain buildup in the area. During this process, very small fractures are formed in the rocks, which help to contribute more radon to the soilgas near the Earth's surface. A decreasing radon anomaly may be due to the squeezing effect of compressional stress in rock, which changes the porosity of soil at a microscale (Ramola et al. 2008; Kumar et al. 2009).

To express the significance of the seismic event at the measurement site a number of empirical relations between earthquake magnitude and the radius of the effective precursory manifestation zone have been given by various authors (Dobrovolsky et al. 1979; Fleischer 1981; Hauksson and Goddard 1981; Sultankhodzhayev 1984; Friedmann 1991). Walia et al. 2003 proposed a relationship between the amplitude of radon anomaly (A), epicentral distance (D) and earthquake magnitude (M) for NW Himalayas.

The analysis of relation between precursor time (Rikitake 1979) epicentral distance (Dobrovolsky et al. 1979; Fleischer 1981) and earthquake magnitudes (Hauksson and Goddard 1981; Friedmann 1991; Walia et al. 2003) shows that there is no universal empirical relationship, which is valid for interpretation of radon data for all earthquake magnitudes. The following standard dislocation model and criteria for the quake selection is applied (Planinić et al. 2004).

The Earthquake of every magnitude at the distance (D) less than or equal to $10 \mathrm{~km}$ from the monitoring site is selected; Also in case of $\mathrm{M} \geq 2,10<\mathrm{D} \leq 100$; for $\mathrm{M} \geq 3,100<$ $\mathrm{D} \leq 200$; and for $\mathrm{M} \geq 4$, D > 200 (Wattananikorn et al. 1998; Planinić et al. 2004; Miklavčić et al. 2008). Table 6 shows the seven events selected from NW Himalaya data using the above criteria. In the case of spatially and temporally 
clustered earthquakes, the largest earthquake is assumed to precede the radon anomaly (Hartmann and Leavy 2005).

Similar kind of study is carried out in Kangra Valley of NW Himalayas, India (Kumar et al. 2009). The above standard dislocation model and criteria for the quake selection is applied (Planinić et al. 2004) to the data of Kangra Valley
NW Himalayas (Kumar et al. 2009) and Tables 7 and 8 show the number of events selected and correlated with radon anomalies in soil gas and ground water from Kangra Valley.

The precursory phenomena can be observed beyond the distance $\mathrm{D}(\mathrm{km})$, which is roughly the radius of the effective precursory manifestation zone. The size of this zone

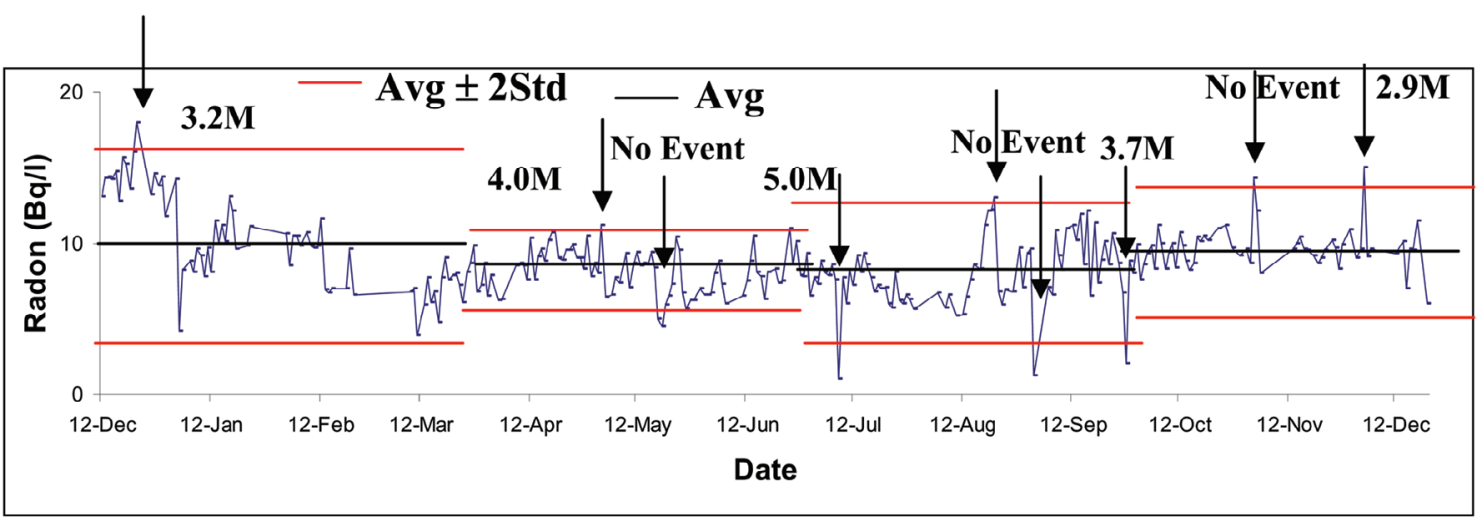

Fig. 5. Daily variation of radon concentration in ground water at Banikhet from December 2006 to December 2007.

Table 4. Seasonal average value of radon concentration in ground water at Banikhet.

\begin{tabular}{|c|c|c|c|c|}
\hline Parameters & Time Period & Average (Avg.) & $\begin{array}{c}\text { Standard Deviation } \\
\text { (Std.) }\end{array}$ & $\begin{array}{c}\% \text { Variation Coefficient } \\
\text { (Std./Avg.) }\end{array}$ \\
\hline \multirow{4}{*}{$\operatorname{Radon}\left(\mathrm{Bq} 1^{-1}\right)$} & December 2006 - March 2007 & 9.8 & 3.1 & 31.6 \\
\hline & April - June 2007 & 8.2 & 1.5 & 18.2 \\
\hline & July - September 2007 & 7.2 & 3.1 & 47.3 \\
\hline & October - November 2007 & 8.9 & 2.8 & 31.4 \\
\hline
\end{tabular}

Table 5. Correlation of Radon anomalies recorded at Banikhet in ground water with seismic event.

\begin{tabular}{|c|c|c|c|c|c|c|c|}
\hline Date of anomaly & Date of Event & $\begin{array}{l}\text { Longitude } \\
\text { (deg.E) }\end{array}$ & $\begin{array}{c}\text { Latitude } \\
\text { (deg.N) }\end{array}$ & $\begin{array}{l}\text { Depth } \\
\text { (Kms) }\end{array}$ & Magnitude & $\begin{array}{c}\text { Epicenter Distance } \\
\text { (Kms) }\end{array}$ & $\begin{array}{c}\text { Precursor Time } \\
\text { (Days) }\end{array}$ \\
\hline $22 / 12 / 06$ & $25 / 12 / 06$ & 76.6 & 30.9 & 10.0 & 3.2 & 197 & 3 \\
\hline $02 / 05 / 07$ & $02 / 05 / 07$ & 79.4 & 31.6 & - & 4.0 & 339 & - \\
\hline $19 / 05 / 07 *$ & \multicolumn{6}{|c|}{ No Event } & \\
\hline 08/07/07* & $22 / 07 / 07$ & 78.2 & 33.0 & 15.0 & 5.0 & 210 & 14 \\
\hline $\begin{array}{l}21 / 08 / 07 \\
01 / 09 / 07 *\end{array}$ & \multicolumn{6}{|c|}{ No Event } & \\
\hline $27 / 09 / 07^{*}$ & $04 / 10 / 07$ & 76.2 & 32.6 & 4.5 & 3.7 & 22 & 7 \\
\hline $02 / 11 / 07$ & \multicolumn{6}{|c|}{ No Event } & \\
\hline 03/12/07 & $06 / 12 / 07$ & 76.3 & 32.5 & - & 2.9 & 30 & 3 \\
\hline
\end{tabular}

* Negative Anomaly 
Table 6. No of event selected from NW Himalaya data using standard dislocation model and criteria for the quake selection.

\begin{tabular}{ccccc}
\hline Date of Event & Longitude (deg.E) & Latitude (deg.N) & Depth (Kms) & Magnitude \\
\hline $10 / 12 / 06$ & 77.0 & 31.6 & 10.0 & 3.9 \\
$25 / 12 / 06$ & 76.6 & 30.9 & - & 3.2 \\
$02 / 05 / 07$ & 79.4 & 31.6 & 15.3 & 4.0 \\
$07 / 07 / 07$ & 76.7 & 31.9 & 15.0 & 2.2 \\
$22 / 07 / 07$ & 78.2 & 33.0 & 4.5 & 3.0 \\
$04 / 10 / 07$ & 76.2 & 32.6 & - & 3.7 \\
$06 / 12 / 07$ & 76.3 & 32.5 & 2.9 \\
\hline
\end{tabular}

Table 7. Correlation of Radon anomalies recorded at Palampur in soil gas with seismic event.

\begin{tabular}{cccccccc}
\hline Date of anomaly & Date of Event & $\begin{array}{c}\text { Longitude } \\
\text { (deg.E) }\end{array}$ & $\begin{array}{c}\text { Latitude } \\
\text { (deg.N) }\end{array}$ & $\begin{array}{c}\text { Depth } \\
\text { (Kms) }\end{array}$ & Magnitude & $\begin{array}{c}\text { Epicenter Distance } \\
\text { (Kms) }\end{array}$ & $\begin{array}{c}\text { Precursor Time } \\
\text { (Days) }\end{array}$ \\
\hline $09 / 07 / 07 *$ & $22 / 07 / 07$ & 78.2 & 33.0 & 15.0 & 5.0 & 188 & 13 \\
$02 / 10 / 07$ & $04 / 10 / 07$ & 76.2 & 32.6 & 4.5 & 3.7 & 62 & 5 \\
$19 / 01 / 08$ & $24 / 01 / 08$ & 76.7 & 32.1 & 11.0 & 2.8 & 2.6 & 79 \\
$08 / 06 / 08$ & $13 / 06 / 08$ & 77.1 & 31.6 & 4.2 & & 5 \\
\hline
\end{tabular}

* Negative Anomaly

Table 8. Correlation of Radon anomalies recorded at Dharamshala in ground water with seismic event.

\begin{tabular}{cccccccc}
\hline Date of anomaly & Date of Event & $\begin{array}{c}\text { Longitude } \\
(\mathbf{d e g . E})\end{array}$ & $\begin{array}{c}\text { Latitude } \\
\text { (deg.N) }\end{array}$ & $\begin{array}{c}\text { Depth } \\
\text { (Kms) }\end{array}$ & Magnitude & $\begin{array}{c}\text { Epicenter Distance } \\
\text { (Kms) }\end{array}$ & $\begin{array}{c}\text { Precursor Time } \\
\text { (Days) }\end{array}$ \\
\hline $19 / 07 / 07$ & $22 / 07 / 07$ & 33.0 & 78.2 & 33.0 & 5.0 & 199 & 3 \\
$21 / 03 / 08$ & $24 / 03 / 08$ & 32.8 & 76.2 & 16.8 & 3.2 & 67 & 3 \\
\hline
\end{tabular}

can be approximately estimated by using the following formula (Dobrovolsky et al. 1979; Martinelli 1993; Planinić et al. 2004):

$\mathrm{D}=\mathrm{a} \mathrm{e}^{\mathrm{M}}$

where $\mathrm{M}$ is the magnitude of the earthquake, and a is a parameter with value $>1$ depending on the crust structure of the area considered.

Using above equation parameter " $a$ " is calculated from the obtained data (during present investigations) of $\mathrm{NW}$ Himalayas. Its value ranges from 1 to 8 with an average of 2.7 .

Between the precursory time $\mathrm{T}$ (day), the epicentral distance $\mathrm{D}(\mathrm{km})$ and magnitude $\mathrm{M}$ the following empirical relationship was derived (Dobrovolsky et al. 1979; Martinelli 1993):

$\log (\mathrm{DT})=0.63 \mathrm{M}+\mathrm{b}$

value of the parameter $b$ for gaseous geoseismic precursors of earthquakes is given as 0.15 .

However the value of the parameter $b$ calculated from Eq. (2) using the obtained data in the present investigation ranges from -0.4 to 1.2 with an average of 0.3 .

Based on the published data on pre-earthquake radon anomalies, it is recognized that the shape of the peak (and not only the amplitude) could be used as a diagnostic parameter for the forthcoming seismic events (Martinelli 1993; Planinić et al. 2004). The relation between the amplitude 
and duration of the gaseous anomaly and the magnitude of the expected earthquake has the following form:

$\mathrm{M}=\mathrm{KS}^{1 / 2}$

where $\mathrm{K}$ is a correction factor and $\mathrm{S}$ the area of the detected peak anomaly.

Equation (3) was used to calculate the correction factor $\mathrm{K}$ from the area under the peak $\mathrm{S}$ of radon anomaly and is found to be $0.97\left(\mathrm{kBq} \mathrm{m}^{-3} \mathrm{~d}\right)^{-1 / 2}$ for the obtained radon data in NW Himalayas.

By using Eqs. (1), (2) and (3), as well as the values of $\mathrm{a}, \mathrm{b}$ and $\mathrm{K}$. It may be possible to determine the epicentral distance, precursory time and magnitude of an upcoming earthquake.

The present studies reveal that sometimes the anomaly is not observed even when the seismic event has occurred. This necessitates the need for the measurement of other carrier gases in addition to radon for successful prediction of earthquakes.

Similar type of studies have been carried in Croatia by Planinić et al. (2004) and have examined the empirical equations between earthquake magnitude, epicentral distance and precursor time and has determined the respective constants. According to his studies the parameter a can be as large as 19.3 for the geological structure of the eastern Croatia. The calculated values of the $b$ parameter were in the range from 1.23 to 2.08 , and with average value $=1.68$ and the correction factor $=0.44\left(\mathrm{kBq} \mathrm{m}^{-3} \mathrm{~d}\right)^{-1 / 2}$.

The difference in the range of values of the constant $\mathrm{a}, \mathrm{b}$ and $\mathrm{K}$ in the present investigation compared with those calculated by other authors may be due to the difference in geological formation of the studied areas. The seasonable variation of the radon flux may also be the one of reason for this fact.

\section{CONCLUSIONS}

- The radon anomalies observed in the region have been correlated with the seismic events in the magnitude range 2.2 to 5.0. The radon emission is affected by meteorological as well as geophysical/geochemical parameters.

- It may be possible to determine the epicentral distance, precursory time and magnitude of an upcoming earthquake from observed area under the peak of the radon anomaly.

- The measurement of other carrier gases in addition to radon is required for successful prediction of an earthquake.

Acknowledgements The work has been carried out under the DST research project entitled "Seismotectonic studies and Health Risk assessments in the Himalayas with Special Emphasis on Radon and Helium Emission" No. DST/ 23(476)/SU/2004 and the financial support is acknowl- edged. The thanks are due to the Director Wadia Institute of Himalayan Geology, Dehradun for providing the seismic data. Thanks are due to Dr. Vivek Walia, National Center for Research on Earthquake Engineering, NCREE, Taiwan for fruitful suggestions during the work.

\section{REFERENCES}

Al-Tamimi, M. H. and K. M. Abumurad, 2001: Radon anomalies along faults in North of Jordan. Radiat. Meas., 34, 397-400, doi: 10.1016/S1350-4487(01)001 93-7. [Link]

Chyi, L. L., T. J. Quick, T. F. Yang, and C. H. Chen, 2005: Soil gas radon spectra and earthquakes. Terr. Atmos. Ocean. Sci., 16, 763-774.

Dobrovolsky, I. P., S. I. Zubkov, and V. I. Miachkin, 1979: Estimation of the size of earthquake preparation zones. Pure Appl. Geophys., 117, 1025-1044, doi: 10.1007/B F00876083. [Link]

Einarsson, P., P. Theodórsson, Á. R. Hjartardóttir, and G. I. Guðjónsson, 2008: Radon changes associated with the earthquake sequence in June 2000 in the South Iceland seismic zone. Pure Appl. Geophys., 165, 63-74, doi: 10.1007/s00024-007-0292-6. [Link]

Etiope, G. and S. Lombardi, 1995: Evidence for radon transport by carrier gas through faulted clays in Italy. $J$. Radioanal. Nucl. Chem., 193, 291-300, doi: 10.1007/ BF02039886. [Link]

Fleischer, R. L., 1981: Dislocation model for radon response to distant earthquakes. Geophys. Res. Lett., 8 , 477-480, doi: 10.1029/GL008i005p00477. [Link]

Friedmann, H., 1991: Continuous spring water radon measurement in Austria and possible relations to earthquakes. International Conference on Earthquake Prediction, State-of-the Art, Strasbourg, France.

Fu, C. C., T. F. Yang, V. Walia, and C. H. Chen, 2005: Reconnaissance of soil gas composition over the buried fault and fracture zone in southern Taiwan. Geochem. J., 39, 427-439, doi: 10.2343/geochemj.39.427. [Link]

Guerra, M. and S. Lombardi, 2001: Soil-gas method for tracing neotectonic faults in clay basins: The Pisticci field (Southern Italy). Tectonophysics, 339, 511-522, doi: 10.1016/S0040-1951(01)00072-5. [Link]

Hartmann, J. and J. K. Levy, 2005: Hydrogeological and gasgeochemical earthquake precursors - A review for application. Nat. Hazards, 34, 279-304, doi: 10.1007/ s11069-004-2072-2. [Link]

Hauksson, E. and J. G. Goddard, 1981: Radon earthquake precursor studies in Iceland. J. Geophys. Res., 86, 7037-7054, doi: 10.1029/JB086iB08p07037. [Link]

Igarashi, G., S. Saeki, N. Takahata, K. Sumikawa, S. Tasaka, Y. Sasaki, M. Takahashi, and Y. Sano, 1995: Ground-water radon anomaly before the Kobe earthquake in Japan. Science, 269, 60-61, doi: 10.1126/sci- 
ence.269.5220.60. [Link]

King, C. Y. and A. Minissale, 1994: Seasonal variability of soil-gasradonconcentrationincentralCalifornia.Radiat. Meas., 23, 683-692, doi: 10.1016/1350-4487(94)900 04-3. [Link]

Klusman, R. W., 1993: Soil Gas and Related Methods for Natural Resources Exploration, John Wiley and Sons, New York, 483 pp.

Kumar, A., S. Singh, S. Mahajan, B. S. Bajwa, R. Kalia, and S. Dhar, 2009: Earthquake precursory studies in Kangra valley of North West Himalayas, India, with special emphasis on radon emission. Appl. Radiat. Isot., 67, 1904-1911, doi: 10.1016/j.apradiso. 2009.05.016. [Link]

Lepeltier, C., 1969: A simplified statistical treatment of geochemical data by graphical representation. Econ. Geol., 64, 538-550, doi: 10.2113/gsecongeo.64.5.538. [Link]

Liu, K. K., T. F. Yui, Y. H. Yeh, Y. B. Tsai, and T. L. Teng, 1984/85: Variations of radon content in groundwaters and possible correlation with seismic activities in northern Taiwan. Pure Appl. Geophys., 122, 231-244, doi: 10.1007/BF00874596. [Link]

Martinelli, G., 1993: Fluidodynamical and chemical features of radon 222 related to total gases: Implications foe earthquake predictions. Proceedings of an Advisory Group Meeting on Isotopic and Geochemical Precursors of Earthquakes and Volcanic Eruptions, Vienna, 1991, International Atomic Energy Agency, 48-62.

Miklavčić, I., V. Radolić, B. Vuković, M. Poje, M. Varga, J. Stanić, and J. Planinić, 2008: Radon anomaly in soil gas as an earthquake precursor. Appl. Radiat. Isot., 66, 1459-1466, doi: 10.1016/j.apradiso.2008.03.002. [Link]

Mogro-Campero, A., R. L. Fleischer, and R. S. Likes, 1980: Changes in subsurface radon concentration associated with earthquake. J. Geophys. Res., 85, 3053-3057, doi: 10.1029/JB085iB06p03053. [Link]

Mukherji, P., M. Chatterjee, and K. G. Sen, 2001: Mathematical modelling of radon emanation for earthquake prediction. In: Hunyadi, I., I. Csige, and J. Hakl (Eds.), Proceeding of the $5^{\text {th }}$ International Conference on Rare Gas Geochemistry, Ep Systema, Debrecen, Hungary, 27-35.

Planinić, J., V. Radolić, and B. Vuković, 2004: Radon as an earthquake precursor. Nuclear Instruments and Methods Phys. Res. A, 530, 568-574, doi: 10.1016/j.nima.20 04.04.209. [Link]

Ramola, R. C., Y. Prasad., G. Prasad., S. Kumar, and V. M. Choubey., 2008: Soil-gas radon as seismotectonic indicator in Garhwal Himalaya. Appl. Radiat. Isot., 66 ,1523-1530, doi: 10.1016/j.apradiso.2008.04.006. [Link]

Rikitake, T., 1979: Classification of earthquake precur- sors. Tectonophysics, 54, 293-309, doi: 10.1016/00401951(79)90372-X. [Link]

Scholz, C. H., L. R. Sykes, and Y. P. Aggarwal, 1973: Earthquake prediction: A physical basis. Science, 181, 803-810, doi: 10.1126/science.181.4102.803. [Link]

Sharma, A. K., V. Walia, and H. S. Virk, 2000: Effect of meteorological parameters on radon emanation at Palampur (H.P.). J. Geophys., 21, 45-48.

Singh, B. and H. S. Virk, 1994: Investigation of radon-222 in soil-gas as an earthquake precursor. Nucl. Geophys., 8, 185-193.

Singh, M., R. C. Ramola, S. Singh, and H. S. Virk, 1988: The influence of meteorological parameters on soil gas radon. J. Assoc. Explor. Geophy., 9, 85-90.

Singh, S., D. K. Sharma, S. Dhar, and S. S. Randhawa, 2006: Geological significance of soil gas radon: A case study of Nurpur area, district Kangra, Himachal Pradesh, India. Radiat. Meas., 41, 482-485, doi: 10.1016/j.radmeas.2005.10.009. [Link]

Sultankhodzhayev, A. N., 1984: Hydrogeoseismic precursors to earthquakes. Proceedings of the International Symposium on Earthquake Prediction, UNESCO, Paris, 1979, Terra Sci. Publ. Co., Tokyo, 181-191.

Talwani, P., W. S. Moore, and J. Chiang, 1980: Radon anomalies and microearthquakes at Lake Jocassee, South Carolina. J. Geophys. Res., 85, 3079-3088, doi: 10.1029/JB085iB06p03079. [Link]

Ulomov, V. I. and B. Z. Mavashev, 1967: A Precursor of a strong tectonic earthquake. Acad. Sci. USSR Earth Sci. Sect., 176, 9-11.

Virk, H. S. and B. Singh, 1992: Correlation of radon anomalies with earthquake in Kangra valley. Nucl. Geophys., 6, 293-300

Walia, V., H. S. Virk., B. S. Bajwa, and N. Sharma, 2003: Relationships between radon anomalies and seismic parameters in N-W Himalaya, India. Radiat. Meas., 36, 393-396, doi: 10.1016/S1350-4487(03)00158-6. [Link]

Walia, V., T. C. Su, C. C. Fu, and T. F. Yang, 2005: Spatial variations of radon and helium concentrations in soil-gas across Shan-Chiao fault, northern Taiwan. $R a$ diat. Meas., 40, 513-516, doi: 10.1016/j.radmeas. 2005. 04.011. [Link]

Walia, V., H. S. Virk, and B. S. Bajwa, 2006: Radon precursory signals for some earthquakes of magnitude $>5$ occurred in N-W Himalaya: An overview. Pure Appl. Geophys., 163, 711-721, doi: 10.1007/s00024-0060044-z. [Link]

Walia, V., S. Mahajan, A. Kumar, S. Singh, B. S. Bajwa, S. Dhar, and T. F. Yang, 2008: Fault delineation study using soil-gas method in Dharamsala area, NW Himalayas, India. Radiat. Meas., 43, S337-S342, doi: 10.1016/j.radmeas.2008.04.071. [Link]

Wattananikorn, K., M. Kanaree, and S. Wiboolsake, 1998: 
Soil gas radon as an earthquake precursor: Some considerations on data improvement. Radiat. Meas., 29, 593-598, doi: 10.1016/S1350-4487(98)00079-1. [Link]

Yang, T. F., C. Y. Chou, C. H. Chen, L. L. Chyi, and J. H. Jiang, 2003: Exhalation of radon and it carrier gases in SW Taiwan. Radiat. Meas., 36, 425-429, doi: 10.1016/
S1350-4487(03)00164-1. [Link]

Yang, T. F., V. Walia, L. L. Chyi, C. C. Fu, C. H. Chen, T. K. Liu, S. R. Song, C. Y. Lee, and M. Lee, 2005: Variations of soil radon and thoron concentrations in a fault zone and prospective earthquakes in SW Taiwan. Radiat. Meas., 40, 496-502, doi: 10.1016/j.radmeas.2005.05.017. [Link] 